Gut, 1988, 29, 1249-1252

\title{
Effect of ICS 205-930 (a specific 5-HT 3 receptor antagonist) on gastric emptying of a solid meal in normal subjects
}

\author{
L M A AKKERMANS, A VOS, A HOEKSTRA, J M M ROELOFS, \\ AND M HOROWITZ
}

From the Departments of Surgery and Nuclear Medicine, University Hospital Utrecht, The Netherlands and the Department of Medicine, University of Adelaide, Royal Adelaide Hospital, Adelaide, South Australia

SUMmaRY The effects on gastric emptying of a solid meal of the specific 5-HT 3 -receptor antagonist ICS 205-930, $10 \mathrm{mg}$ and $20 \mathrm{mg}$ intravenously were assessed with a scintigraphic technique in 12 normals. The $50 \%$ emptying time was less, the lag phase was shorter and the post lag emptying rate was faster after $20 \mathrm{mg}$ ICS $205-930(p<0 \cdot 02)$. After $10 \mathrm{mg}$ ICS 205-930 the lag phase was significantly shorter compared with placebo $(p<0 \cdot 04)$. These results suggest that $5-\mathrm{HT}_{3}$ receptors may be involved in the regulation of gastric emptying in man.

ICS 205-930 ([IH]-indol-3-carbonic-acid tropineester hydrochloride, Sandoz, Basle, Switzerland), is a recently synthesised compound which is a potent and highly selective antagonist of 5-hydroxytryptamine (5-HT) at excitatory receptors located on peripheral neurones. ${ }^{12}$ These low affinity 5-HT-M receptors, which have recently been called $5-\mathrm{HT}_{3}$-receptors, are widely distributed through the peripheral nervous system and also occur in the enteric nervous system where they control the release of substance $P$, which activates the smooth muscle cells of the gut wall. ${ }^{23}$

Data obtained in animal studies indicate that 5 - $\mathrm{HT}_{3}$-receptors may play an important role in the regulation of gastrointestinal motility. In vitro, ICS 205-930 and another selective, but less potent $5-\mathrm{HT}_{3}$ receptor antagonist, MDL $72222,{ }^{4}$ increase the electrical field stimulation induced contractions of circular muscle strips from the guinea pig stomach. In fasted guinea pigs gastric emptying of polystyrene coated barium particles is enhanced by ICS 205-930 and another recently synthesised $5-\mathrm{HT}_{3}$-receptor antagonist, GR38032F. ${ }^{6}$ In these actions ICS 205-930 appears to be approximately 10-50 times more potent than metoclopramide. ${ }^{5}$ In isolated preparations of guinea pig ileum ICS 205-930 blocks the 5-HT induced spasm of the longitudinal muscle, but does

Address for correspondence: Dr L M A Akkermans, Department of Surgery, University Hospital, Catharijnesingel 101, 3511 GV Utrecht, The Netherlands. Received for publication 12 April 1988. not affect normal peristalsis, ${ }^{3}$ in contrast with the functional paralysis which occurs after opiates. ICS 205-930 has a potent antiemetic effect in the model of cisplatin induced emesis in the ferret. ${ }^{7}$ 5-HT induces its peripheral painful effects in man through activation of neuronal $5-\mathrm{HT}_{3}$ receptors and these can be selectively and reversibly inhibited by ICS $205-930 .^{2}$

We have evaluated the effect of ICS 205-930, in intravenous doses of $10 \mathrm{mg}$ and $20 \mathrm{mg}$, on gastric emptying of a solid meal in normal human volunteers.

\section{Methods}

SUBJECTS

Twelve normal volunteers (six men, age range 21-28 years) who were non-smokers, on no medication, within $15 \%$ of ideal body weight and without evidence of gastrointestinal disease were studied. Written informed consent was obtained in all cases and the study protocol was approved by the Human Research Review Committee of University Hospital, Utrecht.

All subjects participated in three experiments, each of which was separated by a minimum time interval of seven days. On each of the experimental days $50 \mathrm{ml}$ normal saline, containing either $10 \mathrm{mg}$ ICS 205-930, $20 \mathrm{mg}$ ICS 205-930, or placebo was given at 0845 hours by intravenous infusion over 15 minutes. 
The test doses were given in single blind fashion, and their order of administration was determined by a randomisation list (Latin square design). As the analysis of each gastric emptying study was done by one of the investigators who did not know which substance was infused, the study was in effect double blind.

Gastric emptying was measured with a previously described scintigraphic technique ${ }^{8}$ starting at 0900 hours and continuing for at least two hours. Each subject had fasted from 2200 hours the previous day. The solid test meal consisted of a pancake containing $8.6 \mathrm{~g}$ of protein, $40.2 \mathrm{~g}$ of carbohydrate and $8.4 \mathrm{~g}$ of fat, labelled with $9 \mathrm{MBq}{ }^{99 \mathrm{~m}} \mathrm{Tc}$-tin colloid. The subject was seated, leaning backwards at an angle of $60^{\circ}$ to avoid overprojection of stomach and intestines, and radioactivity was measured by a ventrally positioned large field of view scintillation camera. Data were acquired in frame mode in a 64 by 64 -matrix format with a time resolution of one minute. The data were corrected for subject movement, radionuclide decay and tissue attenuation using previously described methods. ${ }^{9}$ Time activity curves (expressed as percentage retention of the meal $v$ time) were derived for the stomach and the remainder of the abdomen. From each gastric emptying curve the duration of the lag phase before food emptied from the stomach, the linear emptying rate after the lag phase and the time for $50 \%$ emptying were derived for subsequent statistical analysis. ${ }^{89}$ Each gastric emptying test was analysed and interpreted without knowledge of the study medication.

A standard 12-lead electrocardiogram was done immediately before and after each study and during each intravenous infusion the electrocardiogram was monitored continuously. Other safety evaluations included continuous monitoring of pulse rate, and measurement of blood pressure at least every five minutes and body temperature at least every 15 minutes from the start of the intravenous infusion until the completion of the test. On each study day, a thorough clinical examination, haematological and biochemical blood screen and a standard urinalysis were done before and at the end of the test. Each subject was asked to notify the investigators immediately of the occurrence of any possible adverse events during, or after each study period.

Gastric emptying data were analysed using the Wilcoxon's rank-sum test for paired data and changes in cardiovascular, haematological, and biochemical parameters were assessed using analysis of variance.

\section{Results}

All subjects tolerated the study well and no significant effects on cardiovascular, haematological or
Table 1 Gastric emptying of a solid meal in 12 subjects (mean (SE)) given intravenous placebo, ICS 205-930 (10 $\mathrm{mg})$ and ICS 205-930 $(20 \mathrm{mg})$

\begin{tabular}{llll}
\hline & & \multicolumn{2}{l}{ ICS 205-930 ICS 205-930 } \\
& Placebo & I0 mg & 20 mg \\
\hline Lag phase (min) & $17 \cdot 5(2 \cdot 8)$ & $12 \cdot 2(2 \cdot 1)^{*}$ & $11 \cdot 3(2 \cdot 0)^{*}$ \\
Linear emptying rate (\%/h) & $52 \cdot 9(3 \cdot 2)$ & $64 \cdot 0(4 \cdot 9)$ & $63 \cdot 9(3 \cdot 5)^{*}$ \\
50\% emptying time (min) & $76 \cdot 9(5 \cdot 7)$ & $61 \cdot 9(4 \cdot 8)$ & $59 \cdot 8(3 \cdot 8)^{*}$ \\
\hline
\end{tabular}

*Significantly different from placebo $(\mathrm{p}<0 \cdot 05)$.

biochemical parameters were observed. Two subjects reported mild symptoms of constipation and abdominal fullness for approximately 24 hours after the $20 \mathrm{mg}$ dose of ICS 205-930 and one of these two subjects had similar symptoms for approximately 24 hours after the $10 \mathrm{mg}$ dose of ICS 205-930. Otherwise no adverse events were reported.

In all subjects gastric emptying of the solid meal was characterised by an initial lag phase, followed by an emptying phase which closely approximated a linear pattern. The duration of the lag phase was less $(\mathrm{p}<0.01)$, the linear emptying rate was faster $(\mathrm{p}<0.02)$ and the $50 \%$ emptying time was less ( $p<0.01)$ after $20 \mathrm{mg}$ of ICS $205-930$ compared with placebo (Table). After the $10 \mathrm{mg}$ ICS 205-930 the lag phase was less $(p<0.04)$ and there were nonsignificant trends $(p<0.055)$ for a more rapid linear emptying phase and a shorter $50 \%$ emptying time, compared with placebo (Table). There was no significant difference between the $10 \mathrm{mg}$ and $20 \mathrm{mg}$ ICS 205-930 for any of the three parameters.

\section{Discussion}

Previous studies have confirmed that ICS 205-930 is a potent and selective antagonist of neuronal $5-\mathrm{HT}_{3}$ receptors. ${ }^{12}$ Because the affinity of the drug for other common neurotransmitter receptors is negligible, no adverse cardiovascular or central nervous system effects have been reported. ICS 205-930 was well tolerated and effective in 11 patients treated with the drug to prevent cisplatin induced vomiting. ${ }^{10}$ ICS 205-930 has been reported to be effective in the treatment of secretory diarrhoea associated with the carcinoid syndrome, but one of the three patients in this study developed pyrexia and a skin rash which resolved on discontinuation of the drug. ${ }^{11}$ Our study also indicates that intravenous doses of ICS 205-930 are generally well tolerated. The symptoms of constipation and abdominal fullness observed by two subjects were mild, but may have been related to the use of the drug.

The results of our study suggest that $5-\mathrm{HT}_{3}-$ receptors may be involved in the regulation of gastric 
emptying in normal man - that is, an effect of ICS 205-930 is only expected where the underlying mechanisms include the activation of $5-\mathrm{HT}_{3^{-}}$ receptors, ${ }^{2}$ but further studies are required to confirm this hypothesis. The most likely explanation for the effect of ICS 205-930 to facilitate gastric emptying is direct antagonism of 5- $\mathrm{HT}_{3}$-receptors in the stomach, but an action on central nervous system control mechanisms is also possible. The effects of ICS 205-930 on gastric emptying were relatively small (mean reduction in $50 \%$ emptying time of approximately $20 \%$ ), but prokinetic drugs, such as cisapride and metoclopramide, have minimal or no effect on gastric emptying in the normal stomach. ${ }^{12}$ The more rapid gastric emptying of digestible solid food after ICS 205-930 probably results from an increase in antral motility and/or antroduodenal coordination,,$^{13}$ but this requires objective evaluation.

The physiological and pathophysiological role of $5-\mathrm{HT}_{3}$ receptors in the gastrointestinal tract needs further clarification before the implications of therapy - for example, for gastroparesis, with 5- $\mathrm{HT}_{3}$ antagonists such as ICS 205-930 are apparent. ${ }^{2}$ 5-HT in the gastrointestinal tract is mainly stored in the enterochromaffin cells and lower quantities are found in neurones within the myenteric and submucosal plexus. ${ }^{14}$ Very little is known about the conditions which regulate the release of 5-HT from the neuronal stores. Several stimuli, such as acidification of the duodenal mucosa ${ }^{15}$ increased intraluminal pressure in the intestine ${ }^{16}$ and neuronal stimulation ${ }^{17}$ have been shown to stimulate 5-HT release from the enterochromaffin cells.

Results of animal studies suggest that $5-\mathrm{HT}_{3}-$ receptor activation may be involved in some disorders of gastrointestinal motility ${ }^{145}$ and if this

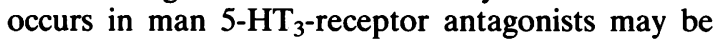
therapeutically useful. ICS 205-930 may also offer some therapeutic advantage over treatments such as anticholinergics, cholinomimetic agents, and opiates, because in contrast with these drugs it appears to have little effect on basal motility. ${ }^{3}$ While metoclopramide is also a 5- $\mathrm{HT}_{3}$ receptor antagonist, ${ }^{18}$ central nervous system side effects occur frequently as a result of its dopamine receptor blocking activity.

Our results indicate that studies evaluating the effect of ICS 205-930 in various forms of gastroparesis are now appropriate.

We acknowledge the support of the Netherlands Organisation for the Advancement of Pure Research (ZWO) and Sandoz, Clinical Research Department, Basle, Switzerland in undertaking this study.

\section{References}

1 Richardson BP, Engel G, Donatsch P, Stadler PA. Indentification of serotonin $\mathrm{M}$-receptor subtypes and their specific blockade by a new class of drugs. Nature 1985; 316: 126-31.

2 Richardson BP, Engel G. The pharmacology and function of 5- $\mathrm{HT}_{3}$ receptors. TINS 1986; 9: 424-8.

3 Buchheit KH, Engel G, Mutschler E, Richardson B. Study of the contractile effect of 5-hydroxytryptamine (5-HT) in the isolated longitudinal muscle strip from guinea-pig ileum. Naunyn-Schmied. Arch Pharmacol 1985; 329: 36-41.

4 Fozard JR. MDL 72222: a potent and highly selective antagonist at neuronal 5-hydroxytryptamine receptors. Naunyn-Schmied. Arch Pharmacol 1984; 326: 36-44.

5 Buchheit KH, Costall B, Engel G, Gunning SJ, Naylor RJ, Richardson BP. 5-Hydroxytryptamine receptor antagonism by metoclopramide and ICS 205-930 in the guinea-pig leads to enhancement of contractions of stomach strips induced by electrical field stimulation and facilitation of gastric emptying in-vivo. $J$ Pharm Pharmacol 1985; 37: 664-7.

6 Costall B, Gunning SJ, Naylor RJ, Tyers MB. The effect of $\mathrm{CR} 38032 \mathrm{~F}$, novel $5-\mathrm{HT}_{3}$-receptor antagonist on gastric emptying in the guinea pig. Br J Pharmacol 1987; 91: 263-4.

7 Costall B, Domeney AM, Naylor RJ, Tattersall FD. 5Hydroxytryptamine M-receptor antagonism to prevent cisplatin-induced emesis. Neuropharmacology 1986; 25: 959-61. .

8 Smout AJPM, Akkermans LMA, Roelofs JMM, Pasma FG, Oei HY, Wittebol P. Gastric emptying and postprandial symptoms after Billroth II resection. Surgery 1987; 101: 27-34.

9 Collins PJ, Horowitz M, Shearman DJC, Chatterton $\mathrm{BE}$. Correction for tissue attenuation in radionuclide gastric emptying studies: A comparison of a lateral image method and a geometric mean method. $\mathrm{Br} J$ Radiol 1984; 57: 689-95.

10 Leibundgut U, Lancranjan I. First results with ICS $205-930\left(5-\mathrm{HT}_{3}\right.$ receptor antagonist) in prevention of chemotherapy-induced emesis. Lancet 1987; i: 1198.

11 Anderson JV, Coupe MO, Morris JA, Hodgson HJF, Bloom SR. Remission of symptoms in carcinoid syndrome with a new 5-hydroxytryptamine $M$ receptor antagonist. Br Med J 1987; 294: 1129.

12 Edwards CA, Holden S, Brown C, Read NW. Effect of cisapride on the gastrointestinal transit of a solid meal in normal human subjects. Gut 1987; 28: 13-6.

13 Meyer JH. Motility of the stomach and gastroduodenal junction. In: Leonard R Johnson, ed. Physiology of the gastrointestinal tract. New York: Raven Press, 1987: 613-29.

14 Furness JB, Costa M. Neurons with 5-hydroxytryptamine like immuno-reactivity in the enteric nervous system: their projection in the guinea pig small intestine. Nervosa 1982; 7: 341-9.

15 Jaffe BM, Kopen DF, Lazan DW. Endogeneous serotonin in the control of gastric acid secretion. Surgery 1977; 82: 156-63.

16 Burks TF, Long JP. 5-Hydroxytryptamine release into 
dog intestinal musculature. Am J Physiol 1966; 211: 619-25.

17 Pettersson G. The neural control of the serotonin content in mammalian enterochromaffin cells. Acta
Physiol Scand 1979: suppl. 470.

18 Fozard JR, Mobarok Ali ATM. Blockade of neuronal tryptamine receptors by metoclopramide. Eur $J$ Pharmacol 1978; 49: 109-12. 